\title{
Postharvest quality of celeriac [Apium graveolens L. var. rapaceum (Mill.) Gaud.] depending on weed control methods
}

\author{
Jakość pozbiorcza selera korzeniowego [Apium graveolens L. \\ var. rapaceum (Mill.) Gaud.] w zależności od metody ochrony \\ przed chwastami
}

\author{
Ryszard Kosson, Zbigniew Anyszka, Maria Grzegorzewska, Joanna Golian, \\ Małgorzata Kohut, Ewa Badełek
}

\begin{abstract}
Summary
The studies were conducted in 2010-2012 at the Research Institute of Horticulture in Skierniewice. The aim of the research was to determine the yield of celeriac, its storage ability and nutritional value, depending on weed management methods. In the field experiments the following methods were compared: the use of herbicides, herbicide + mechanical treatment, mechanical treatments, soil mulching with polypropylene and biodegradable foil, soil mulching with polypropylene + biostymulant AlgaminoPlant and hand weeding. After harvest celeriac roots were stored at the temperature $0^{\circ} \mathrm{C}$ for $213-216$ days and after storage were sorted out into the following groups: healthy roots without symptoms of re-growing, healthy roots with symptoms of re-growing, roots with diseases and rotting symptoms. The natural weigh loss was also determined. Chemical analyses were performed after harvest and storage period. These analyses consisted of evaluation of dry matter, ascorbic acid, total sugars and soluble phenols content. The highest yield after the storage period was obtained from plants treated with linuron and additionally mechanically weeded and the lowest from not weeded. After the storage the lower contents of dry matter, in comparison to stored celeriac, were determined. Ascorbic acid contents in celeriac grown in biodegradable foil and weeded by hand was higher than in other methods. The contents of soluble phenols after storage was higher than after harvest, except celeriac treated with flurochloridone.
\end{abstract}

Key words: celeriac; weed control; storage ability; nutritional value

\section{Streszczenie}

W latach 2010-2012, w Instytucie Ogrodnictwa w Skierniewicach przeprowadzono badania nad określeniem wpływu różnych sposobów odchwaszczania na plonowanie selera korzeniowego, jego trwałość przechowalniczą oraz wartość odżywczą po zbiorze i po przechowywaniu. Porównywano następujące metody odchwaszczania: stosowanie herbicydów, herbicyd + pielenie mechaniczne, same zabiegi mechaniczne, mulczowanie gleby włókniną ściółkującą i folią biodegradowalną, mulczowanie gleby włókniną ściółkującą + biostymulator AlgaminoPlant oraz pielenie ręczne. Po zbiorze korzenie selera przechowywano w temperaturze $0^{\circ} \mathrm{C}$, przez $213-216$ dni, zależnie od roku. Po przechowaniu korzenie sortowano na poszczególne frakcje: korzenie zdrowe niewyrośnięte i wyrośnięte w nowe liście $\mathrm{i}$ korzenie oraz korzenie chore, nadgniłe $\mathrm{i}$ zgniłe, a także określano naturalne ubytki masy. Po zbiorze i po przechowywaniu określano w selerach zawartość suchej masy, witaminy C, cukrów ogółem i fenoli rozpuszczalnych. Najwyższy średni plon handlowy po przechowywaniu uzyskano w selerach traktowanych linuronem w zmniejszonej dawce i pielonych mechanicznie, a najniższy w nieodchwaszczanych. Analizy chemiczne korzeni handlowych selera po przechowaniu wykazały niższą średnią zawartość suchej masy w porównaniu do selera po zbiorze. Zawartość witaminy C w selerach odchwaszczanych ręcznie i mulczowanych folią biodegradowalną była istotnie wyższa w porównaniu z innymi metodami. Nie wykazano wpływu metody ochrony selera przed chwastami na zawartość cukrów ogółem po okresie przechowywania. Stwierdzono wyższą zawartość fenoli rozpuszczalnych po przechowywaniu niż po zbiorze, z wyjątkiem selera opryskiwanego w trakcie uprawy herbicydem flurochloridon.

Słowa kluczowe: seler korzeniowy; metody ochrony; przechowywanie; wartość odżywcza

$\overline{\text { Instytut Ogrodnictwa }}$

Konstytucji 3 Maja 1/3, 96-100 Skierniewice

ryszard.kosson@inhort.pl 


\section{Wstęp / Introduction}

Uprawa selera korzeniowego [Apium graveolens L. var. rapaceum (Mill.) Gaud.] bez odpowiedniej ochrony przed chwastami prowadzi do obniżenia plonu i pogorszenia jego jakości (Dobrzański 1999). Metoda integrowana, preferowana obecnie w zapobieganiu i zwalczaniu chwastów jest efektywna pod względem skuteczności, jak i zdrowotności uzyskiwanych produktów (Dobrzański 1994). Do zapobiegania zachwaszczeniu można wykorzystywać ściółki naturalne lub syntetyczne, np. z czarnej włókniny polipropylenowej czy folii polietylenowej, które stanowią bariery fizyczne, uniemożliwiając dostęp światła i wschody chwastów (Grundy i Bond 2007). W czasie wegetacji chwasty można niszczyć mechanicznie lub ręcznie (Adamczewski i Dobrzański 2008). Do niszczenia chwastów w selerach zalecane są herbicydy zawierające substancje czynne - linuron i flurochloridon (Anyszka i wsp. 1992; Dobrzański 1994). Z uwagi na mały asortyment dopuszczonych do stosowania herbicydów, wykorzystanie innych metod ochrony ma istotne znaczenie dla tej rośliny. Zabiegi odchwaszczające w różnym stopniu modyfikują warunki wzrostu roślin, dlatego też mogą wpływać na wartość odżywczą $i$ trwałość przechowalniczą selera.

O wartości odżywczej selera korzeniowego decyduje zawartość niektórych składników (błonnik pokarmowy 4,9\%, związki mineralne $-0,94 \%$, w tym potas $320 \mathrm{mg} / 100 \mathrm{~g}$, witamina $\mathrm{C}-6,0-8,2 \mathrm{mg} / 100 \mathrm{~g}$, foliany $-12,0 \mathrm{mg} / 100 \mathrm{~g}$, cukry ogółem - 2,25\%, witamina K - $100 \mathrm{mg} / 100 \mathrm{~g}$ ) (Souci i wsp. 2000; Kunachowicz i wsp. 2005). Oprócz zawartości witamin, związków mineralnych i błonnika pokarmowego seler jest spożywany ze względu na jego właściwości prozdrowotne, w tym obniżanie ciśnienia krwi (Pitchford 2000), obniżanie poziomu tłuszczów we krwi (Tsi i Tan 2000) oraz potencjalne działanie antykancerogenne (Hertog i wsp. 1992; Crozier i wsp. 1997; Christensen i Brandt 2006).

Długość okresu przechowywania selera zależy m.in. od warunków uprawy i budowy morfologicznej roślin (Adamicki i Czerko 2002). Na trwałość przechowalniczą wpływają: odmiana, nawożenie i nawadniane, ochrona przed chorobami, szkodnikami i chwastami, a także właściwy termin i sposób zbioru (Adamicki i Czerko 2002; Ostrowska i Robak 2009; Eldin i wsp. 2011). Staranne przygotowanie korzeni do przechowywania, czyli przycięcie liści, korzeni bocznych i szybkie schłodzenie towaru wpływa na utrzymanie lepszej zdrowotności podczas przechowywania i w konsekwencji niższe straty (Greenberg 2012). Optymalne warunki przechowania selera korzeniowego to temperatura $0-1{ }^{\circ} \mathrm{C}$ i wilgotność względna powietrza 95-98\%. W takich warunkach korzenie selera można przechować przez okres 6-8 miesięcy (Weichmann 1977; Adamicki i Czerko 2002).

Celem badań było określenie wpływu różnych metod ochrony przed chwastami na wysokość plonów i trwałość przechowalniczą selera korzeniowego oraz jego wartość odżywczą w okresie pozbiorczym.

\section{Materiały i metody / Materials and methods}

Badania przeprowadzono w latach 2010-2012. Selery uprawiano na polu doświadczalnym Instytutu Ogrodnictwa w Skierniewicach, na glebie płowej, utworzonej z utworów piaskowych na glinie zwałowej, zawierającej 1,3-1,5\% substancji organicznych ( $\mathrm{pH}$ 6,5). Doświadczenia polowe zakładano metodą losowanych bloków, w układzie jednoczynnikowym, w 4 powtórzeniach. Wielkość poletek wynosiła $9 \mathrm{~m}^{2}$, a odchwaszczanych mechanicznie $-12,2 \mathrm{~m}^{2}$. Rozsadę selera, odmiany Diamant, sadzono 26 maja 2010 i 18 maja 2011 roku. W doświadczeniach polowych porównywano następujące metody ochrony przed chwastami: stosowanie herbicydów, herbicyd w obniżonej dawce w połączeniu z zabiegami mechanicznymi, same zabiegi mechaniczne, ściółkowanie (mulczowanie) gleby czarną włókniną ściółkującą (PP) i folią biodegradowalną (PE), ściółkowanie gleby włókniną ściółkującą z zastosowaniem biostymulatora AlgaminoPlant oraz pielenie ręczne.

W doświadczeniach stosowano następujące herbicydy: flurochloridon (Racer $250 \mathrm{EC}$ ) w dawce $750 \mathrm{~g} / \mathrm{ha}$, w terminie do 3 dni po sadzeniu (zabieg $\mathrm{T}_{1}$ ), linuron (Afalon Dyspersyjny $450 \mathrm{SC}$ ) - 450 i $900 \mathrm{~g} / \mathrm{ha}$, w 2-3 tygodnie po sadzeniu $\left(\mathrm{T}_{2}\right)$ oraz chizalofop-P-etylowy (Targa Super 05 EC) - $150 \mathrm{~g} / \mathrm{ha}$, po wschodach chwastów jednoliściennych $\left(\mathrm{T}_{3}\right)$. W selerach mulczowanych włókniną ściółkującą zastosowano też biostymulator AlgaminoPlant $\mathrm{w}$ dawce 0,5 1/ha, wykonując 4 zabiegi co 3 tygodnie od sadzenia. Środki aplikowano poletkowym opryskiwaczem kołowym na sprężone powietrze, zaopatrzonym w rozpylacze płaskostrumieniowe Tee-Jet 8002 VS. Ilość cieczy użytkowej wynosiła 220 1/ha, przy ciśnieniu roboczym 0,3 MPa. Selery zbierano w fazie dojrzałości zbiorczej, w dniach 11.10.2010 i 5.10.2011 roku. W czasie zbioru pobierano próby do przechowywania.

Badania $\mathrm{z}$ przechowywaniem selera korzeniowego przeprowadzono w Pracowni Przechowalnictwa i Fizjologii Pozbiorczej Warzyw, a analizy zawartości składników odżywczych w Pracowni Przetwórstwa i Oceny Jakości Warzyw. Doświadczenia z przechowywaniem selera zakładano w 4 powtórzeniach, po $10 \mathrm{~kg}$ korzeni. Selery zapakowane do skrzynek uniwersalnych, wyłożonych folią polietylenowa, przechowywano w temperaturze $0^{\circ} \mathrm{C}$, przez okres 216 dni w sezonie 2010/2011 oraz 213 dni w sezonie 2011/2012. Po przechowywaniu korzenie przebierano i określano udział następujących frakcji: zdrowe niewyrośnięte $\mathrm{w}$ nowe liście i korzenie, zdrowe wyrośnięte w nowe liście lub korzenie oraz chore, nadgniłe i zgniłe. Określano również ubytki naturalne masy na podstawie różnicy ciężaru korzeni na początku i na końcu okresu przechowalniczego. Selery handlowe po przechowaniu stanowiły korzenie zdrowe zarówno niewyrośnięte, jak i wyrośnięte, natomiast na straty składały się korzenie chore, nadgniłe i zgniłe oraz ubytki masy.

Zawartość składników odżywczych określano przed rozpoczęciem i po zakończeniu przechowywania selera. Określano zawartość suchej masy - metodą suszarkowowagową, witaminy $\mathrm{C}$ - metodą miareczkową Tillmansa (Pijanowski i wsp. 1964), cukrów ogółem - metodą LuffaSchoorla (PN-A-75101-07. 1990), fenoli rozpuszczalnych - metodą z odczynnikiem Folina-Ciocalteu (Lee i wsp. 
1995; Vinson i wsp. 1998) oraz azotanów - metodą potencjometryczną, z użyciem jonoselektywnej elektrody azotanowej Orion.

Wyniki plonów oraz analiz chemicznych poddano analizie statystycznej w oparciu o program analizy wariancji dla doświadczenia jednoczynnikowego, wykorzystujący test Newmana-Keulsa do oceny różnic między średnimi, przy poziomie istotności 5\%.

\section{Wyniki i dyskusja / Results and discussion}

Badania polowe wykazały zróżnicowany wpływ metod ochrony przed chwastami na plonowanie selera korzeniowego (rys. 1). Najwyższe plony korzeni, niewiele różniące się od siebie, uzyskano po zastosowaniu herbicydów linuron + chizalofop-P-etylowy, z selerów pielonych ręcznie, traktowanych herbicydem flurochloridon oraz mulczowanych włókniną ściółkująca. Plony selera opryskiwanego linuronem w dawce zredukowanej o $50 \%$ i dodatkowo pielonego mechanicznie oraz odchwaszczanego mechanicznie były niższe od innych odchwaszczanych obiektów i od kontroli. Najniższy plon zanotowano w selerze odchwaszczanym mechanicznie. Plony selera o wartości handlowej były nieznacznie mniejsze od plonu ogólnego we wszystkich obiektach. Zastosowanie biostymulatora AlgaminoPlant w selerach mulczowanych włókniną ściółkująca, powodowało zwiększenie plonów ogólnego i handlowego w porównaniu do samego mulczowania włókniną, aczkolwiek różnice były niewielkie.

Selery w obydwu sezonach odznaczyły się słabą trwałością przechowalniczą $\mathrm{z}$ powodu dużej podatności na gnicie. Pomimo starannego przygotowania korzeni do przechowywania, w sposób zalecany przez Adamickiego i Czerko (2002) oraz Greenberga (2012), a także utrzymania właściwej temperatury i wilgotności względnej powietrza według Weichmanna (1977) oraz Adamickiego i Czerko (2002) procent korzeni handlowych po przechowaniu był niski i wynosił, w pierwszym sezonie od 4,1 do $22,4 \%$, natomiast $w$ drugim $22,0-51,6 \%$ (tab. 1). Korzenie w czasie przechowywania nie wykazały żadnej podatności na ponowny rozwój i całą masę towaru handlowego stanowiły korzenie zdrowe i niewyrośnięte. W obydwu sezonach trwałość przechowalnicza selerów pochodzących z obiektów odchwaszczanych była lepsza niż z obiektu kontrolnego poza przypadkiem mulczowania gleby włókniną ściółkującą w 2011 roku. Wcześniej o pozytywnym wpływie zabiegów agrotechnicznych, w tym chemicznych metod ograniczających zachwaszczenie, na efekt przechowalniczy selerów pisali Adamicki i Czerko (2002), Ostrowska i Robak (2009) oraz Eldin i wsp. (2011).

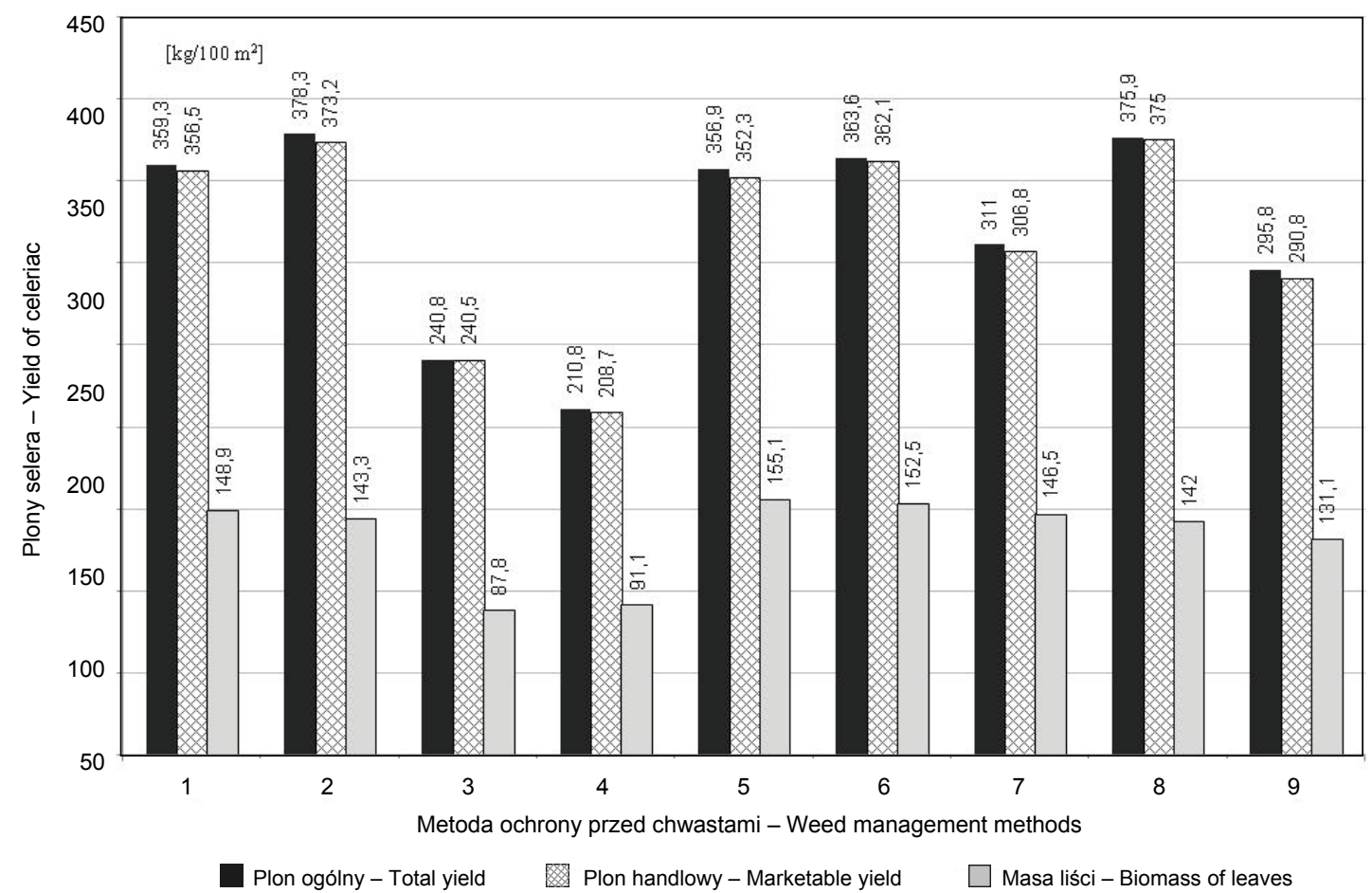

1 - flurochloridone - $750 \mathrm{~g} / \mathrm{ha}\left(\mathrm{T}_{1}\right) ; 2$ - linuron - $900 \mathrm{~g} / \mathrm{ha}\left(\mathrm{T}_{2}\right)+$ quizalofop-P-ethyl $-150 \mathrm{~g} / \mathrm{ha}\left(\mathrm{T}_{3}\right) ; 3-$ linuron $-450 \mathrm{~g} / \mathrm{ha}\left(\mathrm{T}_{2}\right)+\mathrm{zabiegi}$ mechaniczne mechanical treatments $(2 \times) ; 4$ - zabiegi mechaniczne - mechanical treatments $(3 \times) ; 5$ - m mulcz z włókniny ściółkującej - polypropylene mulch (PP); 6 - mulcz z włókniny ściółkującej - polypropylene mulch + AlgaminoPlant $-4 \times 0,5$ 1/ha; 7 - mulcz z folii biodegradowalnej - mulch from biodegradable foil; 8 - pielenie ręczne - hand weeding; 9 - kontrola - check

Rys. 1. Plony selera korzeniowego w uprawie polowej, w zależności od metody ochrony przed chwastami (średnie z 2 lat)

Fig. 1. The yield of celeriac grown in the field, depending on weed control methods (means for 2 years) 
Tabela 1. Procentowy udział selera handlowego (korzenie niewyrośnięte) po przechowaniu, w zależności od metody ochrony przed chwastami

Table 1. The percentage of marketable fraction of celeriac (not re-grown roots) after storage depending on weed control methods

\begin{tabular}{|c|c|c|c|}
\hline $\begin{array}{l}\text { Metoda ochrony przed chwastami } \\
\text { Weed control methods }\end{array}$ & $\begin{array}{c}\text { Sezon przechowalniczy } \\
\text { Storage season } \\
2010 / 2011\end{array}$ & $\begin{array}{c}\text { Sezon przechowalniczy } \\
\text { Storage season } \\
2011 / 2012\end{array}$ & $\begin{array}{l}\text { Średnia z } 2 \text { sezonów } \\
\text { Mean for } 2 \text { seasons }\end{array}$ \\
\hline Flurochloridone $-750 \mathrm{~g} / \mathrm{ha}\left(\mathrm{T}_{1}\right)$ & $21,3 \mathrm{ab}$ & $44,5 \mathrm{ab}$ & $32,9 \mathrm{ab}$ \\
\hline $\begin{array}{l}\text { Linuron - } 900 \mathrm{~g} / \mathrm{ha}\left(\mathrm{T}_{2}\right) \\
+ \text { quizalofop-P-ethyl - } 150 \mathrm{~g} / \mathrm{ha}\left(\mathrm{T}_{3}\right)\end{array}$ & $22,4 \mathrm{ab}$ & $36,4 \mathrm{ab}$ & $29,4 \mathrm{ab}$ \\
\hline $\begin{array}{l}\text { Linuron }-450 \mathrm{~g} / \mathrm{ha}\left(\mathrm{T}_{2}\right) \\
+ \text { zabiegi mechaniczne }- \text { mechanical treatments }(2 \times)\end{array}$ & $34,4 \mathrm{a}$ & $42,6 \mathrm{ab}$ & $38,5 \mathrm{a}$ \\
\hline Zabiegi mechaniczne - Mechanical treatments $(3 \times)$ & $18,4 \mathrm{ab}$ & $36,6 \mathrm{ab}$ & $27,5 \mathrm{ab}$ \\
\hline $\begin{array}{l}\text { Mulcz z włókniny ściółkującej (PP) } \\
\text { Polypropylene mulch (PP) }\end{array}$ & $20,5 \mathrm{ab}$ & $22,0 \mathrm{~b}$ & $21,3 \mathrm{ab}$ \\
\hline $\begin{array}{l}\text { Mulcz z włókniny ściółkującej - Polypropylene mulch } \\
+ \text { AlgaminoPlant }-4 \times 0,5 \mathrm{l} / \mathrm{ha}\end{array}$ & $13,5 \mathrm{ab}$ & $28,4 \mathrm{ab}$ & $21,0 \mathrm{ab}$ \\
\hline $\begin{array}{l}\text { Mulcz z folii biodegradowalnej } \\
\text { Mulch from biodegradable foil }\end{array}$ & $8,6 \mathrm{ab}$ & $33,8 \mathrm{ab}$ & $21,2 \mathrm{ab}$ \\
\hline Pielenie ręczne - Hand weeding & $11,3 \mathrm{ab}$ & $51,6 \mathrm{a}$ & $31,5 \mathrm{ab}$ \\
\hline Kontrola - Check & $4,1 \mathrm{~b}$ & $26,6 \mathrm{ab}$ & $15,4 \mathrm{~b}$ \\
\hline
\end{tabular}

$\mathrm{T}_{1}$ - zabieg do 3 dni po sadzeniu - treatment up to 3 days after planting; $\mathrm{T}_{2}$ - zabieg 2-3 tygodnie po sadzeniu - treatment 2-3 weeks after planting; $\mathrm{T}_{3}$ - zabieg po wschodach chwastów jednoliściennych - treatment post-emergence of grass weeds

Wartości oznaczone tymi samymi literami nie różnią się istotnie przy $\alpha=0,05$ - Values with the same letter do not differ significantly at $\alpha=0.05$

Tabela 2. Procentowy udział frakcji selerów niehandlowych oraz ubytków masy po przechowaniu, w zależności od metody ochrony przed chwastami

Table 2. The percentage of unmarketable fraction and mass losses of celeriac after storage depending on weed control methods

\begin{tabular}{|c|c|c|c|c|c|c|}
\hline \multirow{2}{*}{$\begin{array}{l}\text { Metoda ochrony przed chwastami } \\
\text { Weed control methods }\end{array}$} & \multicolumn{3}{|c|}{$\begin{array}{l}\text { Sezon przechowalniczy } \\
\text { Storage season } \\
2010 / 2011 \\
\end{array}$} & \multicolumn{3}{|c|}{$\begin{array}{l}\text { Sezon przechowalniczy } \\
\text { Storage season } \\
2011 / 2012 \\
\end{array}$} \\
\hline & $\begin{array}{l}\text { chore } \\
\text { sick }\end{array}$ & $\begin{array}{l}\text { nadgniłe } \\
\text { i zgniłe } \\
\text { spoiled } \\
\text { and rotten }\end{array}$ & $\begin{array}{l}\text { ubytki masy } \\
\text { mass losses }\end{array}$ & $\begin{array}{l}\text { chore } \\
\text { sick }\end{array}$ & $\begin{array}{l}\text { nadgniłe } \\
\text { i zgniłe } \\
\text { spoiled } \\
\text { and rotten }\end{array}$ & $\begin{array}{l}\text { ubytki masy } \\
\text { mass losses }\end{array}$ \\
\hline Flurochloridone $-750 \mathrm{~g} / \mathrm{ha}\left(\mathrm{T}_{1}\right)$ & $19,1 \mathrm{ab}$ & $57,6 \mathrm{ab}$ & $2,0 \mathrm{a}$ & $18,1 \mathrm{a}$ & $35,5 \mathrm{ab}$ & $1,9 \mathrm{a}$ \\
\hline $\begin{array}{l}\text { Linuron }-900 \mathrm{~g} / \mathrm{ha}\left(\mathrm{T}_{2}\right) \\
+ \text { quizalofop-P-ethyl }-150 \mathrm{~g} / \mathrm{ha}\left(\mathrm{T}_{3}\right) \\
\end{array}$ & $17,8 \mathrm{ab}$ & $57,6 \mathrm{ab}$ & $2,2 \mathrm{a}$ & $27,7 \mathrm{ab}$ & $34,4 \mathrm{ab}$ & $1,5 \mathrm{a}$ \\
\hline $\begin{array}{l}\text { Linuron }-450 \mathrm{~g} / \mathrm{ha}\left(\mathrm{T}_{2}\right) \\
+ \text { zabiegi mechaniczne }(2 \times)-\text { mechanical } \\
\text { treatments }(2 \times)\end{array}$ & $17,5 \mathrm{ab}$ & $45,7 \mathrm{a}$ & $2,4 \mathrm{a}$ & $22,6 \mathrm{ab}$ & $33,2 \mathrm{ab}$ & $1,6 \mathrm{a}$ \\
\hline $\begin{array}{l}\text { Zabiegi mechaniczne }(3 \times) \\
\text { Mechanical treatments }(3 \times)\end{array}$ & $17,0 \mathrm{ab}$ & $61,9 \mathrm{ab}$ & $2,7 \mathrm{a}$ & $17,1 \mathrm{a}$ & $43,6 \mathrm{ab}$ & $2,7 \mathrm{~b}$ \\
\hline $\begin{array}{l}\text { Mulcz z włókniny ściółkującej (PP) } \\
\text { Polypropylene mulch (PP) }\end{array}$ & $30,1 \mathrm{ab}$ & 46,9 a & $2,5 \mathrm{a}$ & $27,6 \mathrm{ab}$ & $49,0 \mathrm{~b}$ & $1,4 \mathrm{a}$ \\
\hline $\begin{array}{l}\text { Mulcz z włókniny ściółkującej - Polypropylene } \\
\text { mulch }+ \text { AlgaminoPlant }-4 \times 0,5 \mathrm{l} / \mathrm{ha}\end{array}$ & $21,5 \mathrm{ab}$ & $62,2 \mathrm{ab}$ & $2,7 \mathrm{a}$ & 18,6 a & $51,3 \mathrm{~b}$ & $1,7 \mathrm{a}$ \\
\hline $\begin{array}{l}\text { Mulcz z folii biodegradowalnej } \\
\text { Mulch from biodegradable foil }\end{array}$ & $18,5 \mathrm{ab}$ & $70,6 \mathrm{ab}$ & $2,3 \mathrm{a}$ & $19,7 \mathrm{a}$ & $45,0 \mathrm{ab}$ & $1,5 \mathrm{a}$ \\
\hline Pielenie ręczne - Hand weeding & $19,4 \mathrm{ab}$ & $66,7 \mathrm{ab}$ & $2,6 \mathrm{a}$ & $18,5 \mathrm{a}$ & $28,4 \mathrm{a}$ & $1,5 \mathrm{a}$ \\
\hline Kontrola - Check & $3,5 \mathrm{a}$ & $90,0 \mathrm{~b}$ & $2,4 \mathrm{a}$ & $20,4 \mathrm{a}$ & $51,1 \mathrm{~b}$ & $1,9 \mathrm{a}$ \\
\hline
\end{tabular}

$\mathrm{T}_{1}$ - zabieg do 3 dni po sadzeniu - treatment up to 3 days after planting; $\mathrm{T}_{2}$ - zabieg 2-3 tygodnie po sadzeniu - treatment 2-3 weeks after planting; $\mathrm{T}_{3}$ - zabieg po wschodach chwastów jednoliściennych - treatment post-emergence of grass weeds

Wartości oznaczone tymi samymi literami nie różnią się istotnie przy $\alpha=0,05$ - Values with the same letter do not differ significantly at $\alpha=0.05$ 
Tabela 3. Zawartość suchej masy i witaminy $\mathrm{C}$ w selerze świeżym i po przechowywaniu, w zależności od metody ochrony przed chwastami

Table 3. Dry matter and ascorbic acid contents in celeriac, before and after the storage, depending on weed control methods

Średnie z lat 2010-2011 - Means for 2010-2011

\begin{tabular}{|c|c|c|c|c|}
\hline \multirow{2}{*}{$\begin{array}{l}\text { Metoda ochrony przed chwastami } \\
\text { Weed control methods }\end{array}$} & \multicolumn{2}{|c|}{$\begin{array}{c}\text { Sucha masa - Dry matter } \\
{[\%]}\end{array}$} & \multicolumn{2}{|c|}{$\begin{array}{c}\text { Witamina } \mathrm{C}-\text { Ascorbic acid } \\
{[\mathrm{mg} / 100 \mathrm{~g}]}\end{array}$} \\
\hline & $\begin{array}{l}\text { po zbiorze } \\
\text { after harvest }\end{array}$ & $\begin{array}{l}\text { po przechowaniu } \\
\text { after storage }\end{array}$ & $\begin{array}{l}\text { po zbiorze } \\
\text { after harvest }\end{array}$ & $\begin{array}{l}\text { po przechowaniu } \\
\text { after storage }\end{array}$ \\
\hline Flurochloridone $-750 \mathrm{~g} / \mathrm{ha}\left(\mathrm{T}_{1}\right)$ & $12,40 \mathrm{a}$ & $10,82 \mathrm{a}$ & $2,08 \mathrm{~b}$ & $0,63 \mathrm{a}$ \\
\hline $\begin{array}{l}\text { Linuron - } 900 \mathrm{~g} / \mathrm{ha}\left(\mathrm{T}_{2}\right) \\
\text { + quizalofop-P-ethyl - } 150 \mathrm{~g} / \mathrm{ha}\left(\mathrm{T}_{3}\right)\end{array}$ & $11,90 \mathrm{ab}$ & $10,92 \mathrm{a}$ & $2,18 \mathrm{~b}$ & $0,62 \mathrm{a}$ \\
\hline $\begin{array}{l}\text { Linuron }-450 \mathrm{~g} / \mathrm{ha}\left(\mathrm{T}_{2}\right)+\text { zabiegi mechaniczne } \\
(2 \times)-\text { mechanical treatments }(2 \times)\end{array}$ & $12,04 \mathrm{a}$ & $10,91 \mathrm{a}$ & $2,13 \mathrm{~b}$ & $0,76 \mathrm{a}$ \\
\hline $\begin{array}{l}\text { Zabiegi mechaniczne }(3 \times) \\
\text { Mechanical treatments }(3 \times)\end{array}$ & $12,22 \mathrm{a}$ & $11,44 \mathrm{a}$ & $2,34 \mathrm{~b}$ & $0,64 \mathrm{a}$ \\
\hline $\begin{array}{l}\text { Mulcz z włókniny ściółkującej (PP) } \\
\text { Polypropylene mulch (PP) }\end{array}$ & $12,29 \mathrm{a}$ & 10,79 a & $2,45 \mathrm{~b}$ & $0,35 \mathrm{a}$ \\
\hline $\begin{array}{l}\text { Mulcz z włókniny ściółkującej-Polypropylene } \\
\text { mulch }+ \text { AlgaminoPlant }-4 \times 0,51 / \text { ha }\end{array}$ & $11,57 \mathrm{~b}$ & 10,69 a & $2,48 \mathrm{~b}$ & $0,34 \mathrm{a}$ \\
\hline $\begin{array}{l}\text { Mulcz z folii biodegradowalnej } \\
\text { Mulch from biodegradable foil }\end{array}$ & $12,14 \mathrm{a}$ & 10,73 a & $3,19 \mathrm{a}$ & $0,63 \mathrm{a}$ \\
\hline Pielenie ręczne - Hand weeding & $12,04 \mathrm{a}$ & $11,18 \mathrm{a}$ & $3,18 \mathrm{a}$ & $0,30 \mathrm{a}$ \\
\hline Kontrola - Check & $12,06 \mathrm{a}$ & $10,86 \mathrm{a}$ & $3,03 \mathrm{a}$ & 0,49 a \\
\hline
\end{tabular}

$\mathrm{T}_{1}$ - zabieg do 3 dni po sadzeniu - treatment up to 3 days after planting; $\mathrm{T}_{2}-$ zabieg 2-3 tygodnie po sadzeniu - treatment $2-3$ weeks after planting;

$\mathrm{T}_{3}$ - zabieg po wschodach chwastów jednoliściennych - treatment post-emergence of grass weeds

Wartości oznaczone tymi samymi literami nie różnią się istotnie przy $\alpha=0,05-$ Values with the same letter do not differ significantly at $\alpha=0.05$

Tabela 4. Zawartość cukrów prostych i fenoli rozpuszczalnych w selerze świeżym i po przechowywaniu, w zależności od metody ochrony przed chwastami

Table 4. Total content of sugars and soluble phenols in celeriac, before and after the storage depending on weed control methods

Średnie z lat 2010-2011 - Means for 2010-2011

\begin{tabular}{|c|c|c|c|c|}
\hline \multirow{2}{*}{$\begin{array}{l}\text { Metoda ochrony przed chwastami } \\
\text { Weed control methods }\end{array}$} & \multicolumn{2}{|c|}{$\begin{array}{c}\text { Cukry ogółem - Total sugars } \\
{[\%]}\end{array}$} & \multicolumn{2}{|c|}{$\begin{array}{l}\text { Fenole rozpuszczalne }- \text { Soluble phenols } \\
{[\mathrm{mg} / 100 \mathrm{~g}]}\end{array}$} \\
\hline & $\begin{array}{l}\text { po zbiorze } \\
\text { after harvest }\end{array}$ & $\begin{array}{l}\text { po przechowaniu } \\
\text { after storage }\end{array}$ & $\begin{array}{l}\text { po zbiorze } \\
\text { after harvest }\end{array}$ & $\begin{array}{l}\text { po przechowaniu } \\
\text { after storage }\end{array}$ \\
\hline Flurochloridone $-750 \mathrm{~g} / \mathrm{ha}\left(\mathrm{T}_{1}\right)$ & $2,28 \mathrm{abc}$ & $3,40 \mathrm{ab}$ & $28,73 \mathrm{a}$ & $22,58 \mathrm{~b}$ \\
\hline $\begin{array}{l}\text { Linuron - } 900 \mathrm{~g} / \mathrm{ha}\left(\mathrm{T}_{2}\right) \\
\text { + quizalofop-P-ethyl - } 150 \mathrm{~g} / \mathrm{ha}\left(\mathrm{T}_{3}\right)\end{array}$ & $2,51 \mathrm{a}$ & $3,29 \mathrm{ab}$ & $28,00 \mathrm{ab}$ & $38,63 \mathrm{ab}$ \\
\hline $\begin{array}{l}\text { Linuron }-450 \mathrm{~g} / \mathrm{ha}\left(\mathrm{T}_{2}\right)+\text { zabiegi mechaniczne } \\
(2 \times)-\text { mechanical treatments }(2 \times)\end{array}$ & $2,50 \mathrm{a}$ & $3,26 \mathrm{ab}$ & $24,8 \mathrm{abc}$ & $36,65 \mathrm{ab}$ \\
\hline $\begin{array}{l}\text { Zabiegi mechaniczne }(3 \times) \\
\text { Mechanical treatments }(3 \times)\end{array}$ & $2,40 \mathrm{ab}$ & $3,86 \mathrm{a}$ & $25,48 \mathrm{abc}$ & $37,73 \mathrm{ab}$ \\
\hline $\begin{array}{l}\text { Mulcz z włókniny ściółkującej (PP) } \\
\text { Polypropylene mulch (PP) }\end{array}$ & $2,34 \mathrm{ab}$ & $3,47 \mathrm{ab}$ & $21,80 \mathrm{abc}$ & $37,55 \mathrm{a}$ \\
\hline $\begin{array}{l}\text { Mulcz z włókniny ściółkującej - Polypropylene } \\
\text { mulch }+ \text { AlgaminoPlant }-4 \times 0,51 / \text { ha }\end{array}$ & $1,86 \mathrm{~d}$ & $3,70 \mathrm{a}$ & $25,65 \mathrm{abc}$ & $45,10 \mathrm{a}$ \\
\hline $\begin{array}{l}\text { Mulcz z folii biodegradowalnej } \\
\text { Mulch from biodegradable foil }\end{array}$ & $2,08 \mathrm{c}$ & $3,11 \mathrm{~b}$ & $20,58 \mathrm{bc}$ & $45,30 \mathrm{a}$ \\
\hline Pielenie ręczne - Hand weeding & $2,25 \mathrm{bc}$ & $3,44 \mathrm{ab}$ & $19,95 \mathrm{c}$ & $42,55 \mathrm{a}$ \\
\hline Kontrola - Check & $2,23 \mathrm{bc}$ & $3,37 \mathrm{ab}$ & $23,75 \mathrm{abc}$ & $38,95 \mathrm{ab}$ \\
\hline
\end{tabular}

$\mathrm{T}_{1}$ - zabieg do 3 dni po sadzeniu - treatment up to 3 days after planting; $\mathrm{T}_{2}$ - zabieg 2-3 tygodnie po sadzeniu - treatment 2-3 weeks after planting;

$\mathrm{T}_{3}$ - zabieg po wschodach chwastów jednoliściennych - treatment post-emergence of grass weeds

Wartości oznaczone tymi samymi literami nie różnią się istotnie przy $\alpha=0,05$ - Values with the same letter do not differ significantly at $\alpha=0.05$ 


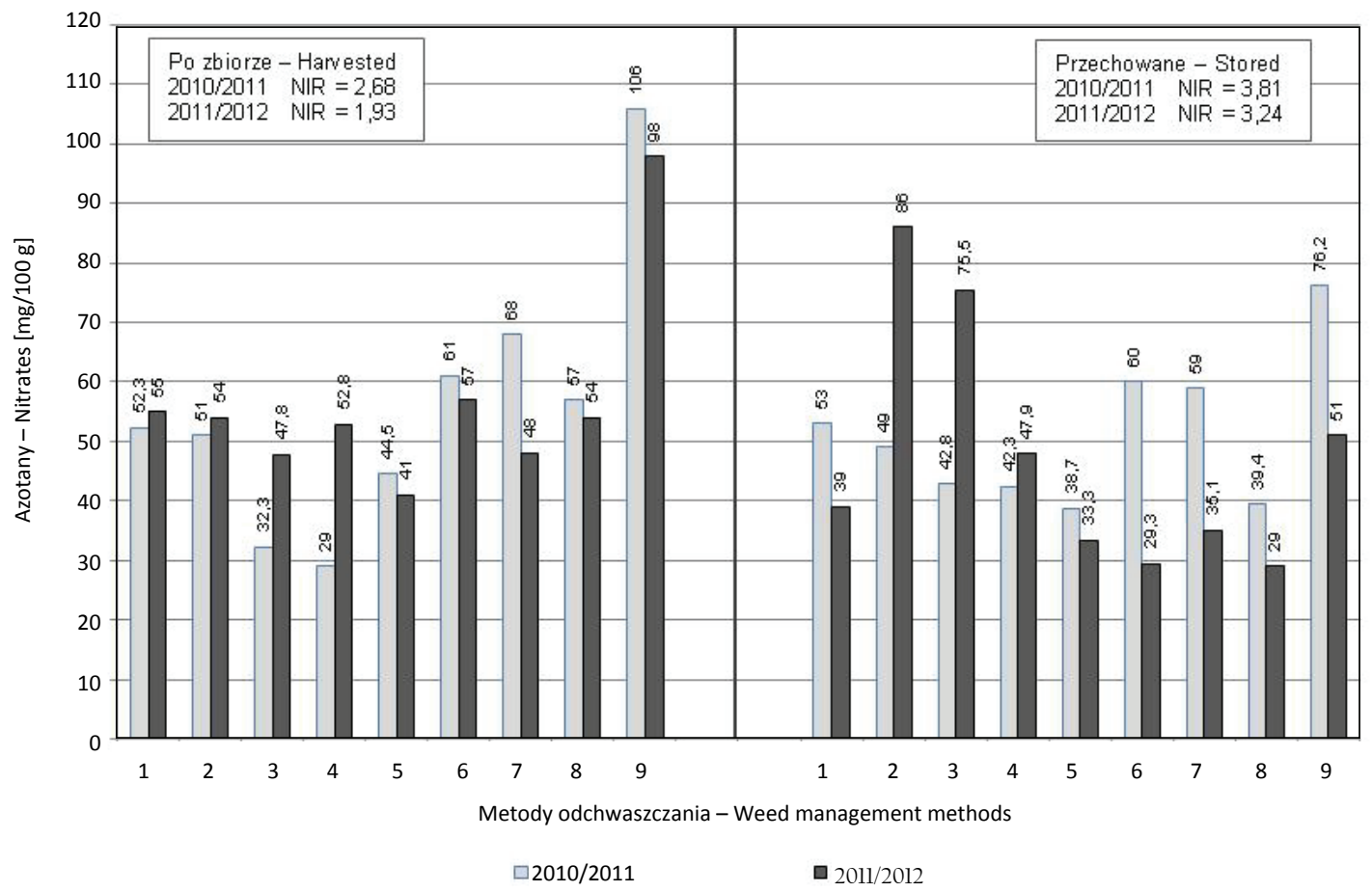

1 - flurochloridone - $750 \mathrm{~g} / \mathrm{ha}\left(\mathrm{T}_{1}\right) ; 2$ - linuron $-900 \mathrm{~g} / \mathrm{ha}\left(\mathrm{T}_{2}\right)+$ quizalofop-P-ethyl $-150 \mathrm{~g} / \mathrm{ha}\left(\mathrm{T}_{3}\right) ; 3-1$ inuron $-450 \mathrm{~g} / \mathrm{ha}\left(\mathrm{T}_{2}\right)+\mathrm{zabiegi}$ mechaniczne - mechanical treatments $(2 \times) ; 4$ - zabiegi mechaniczne - mechanical treatments $(3 \times)$; 5 - mulcz z włókniny ściółkującej polypropylene mulch (PP); $6-$ mulcz z włókniny ściółkującej - polypropylene mulch + AlgaminoPlant $-4 \times 0,51 /$ ha; $7-$ mulcz z folii biodegradowalnej - mulch from biodegradable foil; 8 - pielenie ręczne - hand weeding; 9 - kontrola - check NIR $(0,05)-\operatorname{LSD}(0.05)$

Rys. 2. Zawartość azotanów w selerach po zbiorze i po przechowaniu, w zależności od metody ochrony przed chwastami (sezon 2010/2011 oraz 2011/2012)

Fig. 2. Nitrates contents in celeriac before and after the storage, depending on weed management methods (season 2010/2011 and 2011/2012)

Podsumowując wyniki $\mathrm{z}$ dwóch sezonów można stwierdzić, że najlepszy efekt przechowania uzyskano dla selerów $\mathrm{z}$ poletek opryskiwanych herbicydami linuron $(900 \mathrm{~g} / \mathrm{ha})+$ chizalofop-P-etylowy (150 g/ha), nieco gorszy dla opryskiwanych flurochloridonem w dawce $750 \mathrm{~g} / \mathrm{ha}$ oraz dla selerów pielonych ręcznie. Najmniej towaru handlowego, a tym samym najwyższe straty stwierdzono (poza kontrolą) dla obiektów, w których wykonano mulczowanie gleby (tab. 1, 2).

Nie zaobserwowano istotnych różnic w zawartości składników odżywczych w selerach świeżych (po zbiorze), odchwaszczanych różnymi metodami. Zawartość witaminy $\mathrm{C}$ w selerach po zbiorze $(2,08-3,19 \mathrm{mg} / 100 \mathrm{~g})$ była niższa od wartości podawanych w literaturze (Souci i wsp. 2000; Kunachowicz i wsp. 2005). Po przechowywaniu selerów zawartość tego składnika spadała do poziomu poniżej $1 \mathrm{mg} / 100 \mathrm{~g}$, niezależnie od wcześniej stosowej metody odchwaszczania. Obniżało to istotnie wartość odżywczą selera przechowywanego przez tak długi okres. Zawartość cukrów ogółem w selerach świeżych jest zgodna $\mathrm{z}$ danymi literaturowymi (Souci i wsp. 2000; Kunachowicz i wsp. 2005), przy czym widoczny jest wpływ mulczowania gleby włókniną ściółkującą z dodatkiem biostymulatora AlgaminoPlant na spadek zawartości tego składnika w selerach (tab. 3, 4).

Wzrost zawartości cukrów ogółem (cukry proste + sacharoza) w selerach po przechowywaniu, niezależnie od metody ochrony przed chwastami, wskazuje na zacho- dzący proces hydrolizy skrobi w składowanych selerach. Fenole rozpuszczalne występowały w selerach świeżych w zakresie stężeń od 19,95 (pielenie ręczne) do 28,73 $\mathrm{mg} / 100 \mathrm{~g}$ (flurochloridon). W okresie przechowywania nastąpił wzrost zawartości fenoli rozpuszczalnych w selerach, zwłaszcza w obiektach doświadczalnych, gdzie stosowano mulczowanie gleby folia biodegradowalną oraz pielenie ręczne (tab. 4). Selery nie gromadziły dużych ilości azotanów, niezależnie od metody ochrony przed chwastami w czasie uprawy (rys. 2). Poziom ich zawartości w selerach po zbiorze wahał się w granicach pomiędzy 29 a $70 \mathrm{mg} / 100 \mathrm{~g}$, z wyjątkiem kontroli, gdzie w obu latach badań stwierdzano około $100 \mathrm{mg}$ azotanów w 100 g świeżej masy selera. Po okresie przechowywania notowano spadek zawartości azotanów w selerach, z wyjątkiem selerów traktowanych herbicydami linuron + chizalofop-P-etylowy oraz obiektów odchwaszczanych zabiegani mechanicznymi.

\section{Wnioski / Conclusions}

1. Stosowanie herbicydów, mulczowanie włókniną ściółkującą i pielenie ręczne miało największy wpływ na plonowanie selera korzeniowego.

2. Zastosowanie herbicydów oraz pielenie ręczne w czasie wegetacji wpłynęły na utrzymanie lepszej jakości selerów w czasie przechowywania. 
3. Selery z poletek nieodchwaszczanych w czasie wegetacji przechowały się gorzej niż odchwaszczane zarówno chemicznie, jak i mechanicznie.

4. Seler przechowywany charakteryzował się niższą średnią zawartością suchej masy w porównaniu do selera po zbiorze.

5. Zawartość witaminy $\mathrm{C}$ w selerach odchwaszczanych ręcznie, mulczowanych folią biodegradowalną i w kontroli była istotnie wyższa $\mathrm{w}$ porównaniu $\mathrm{z}$ jej zawartością W selerach odchwaszczanych innymi metodami. Przechowywanie wpłynęło na spadek zawartości tego składnika w selerach do poziomu poniżej $1 \mathrm{mg} / 100 \mathrm{~g}$ świeżej masy.

6. Mulczowanie włókniną ściółkującą (PP) wraz z zastosowaniem biostymulanta AlgaminoPlant wpłynęło istotnie na obniżenie zawartości cukrów ogółem $\mathrm{w}$ selerach $\mathrm{w}$ porównaniu $\mathrm{z}$ innymi sposobami odchwaszczania. Nie wykazano wpływu metody ochrony selera przed chwastami na zawartość cukrów ogółem po okresie przechowywania.

7. Stwierdzono wyższą zawartość fenoli rozpuszczalnych W selerze po przechowywaniu niż po jego zbiorze, $\mathrm{z}$ wyjątkiem selera opryskiwanego w trakcie uprawy herbicydem flurochloridon.

Badania przeprowadzono w ramach Programu Wieloletniego „Rozwój zrównoważonych metod produkcji ogrodniczej w celu zapewnienia wysokiej jakości biologicznej i odżywczej produktów ogrodniczych oraz zachowania bioróżnorodności środowiska i ochrony jego zasobów”, realizowanego w Instytucie Ogrodnictwa w Skierniewicach.

\section{Literatura / References}

Adamczewski K., Dobrzański A. 2008. Znaczenie i możliwości wykorzystania metod agrotechnicznych i niechemicznych do regulowania zachwaszczenia w ekologicznej uprawie roślin. s. 221-241. W: „Poszukiwanie nowych rozwiązań w ochronie upraw ekologicznych” (E. Matyjszczyk, red.). Inst. Ochr. Roślin - PIB, Poznań, 393 ss.

Adamicki F., Czerko Z. 2002. Przechowalnictwo warzyw i ziemniaka. PWRiL, Poznań, 324 ss.

Anyszka Z., Dobrzański A., Pałczyński J., Ulińska Z. 1992. Wpływ kilku herbicydów na stopień zniszczenia chwastów i plonowanie selera korzeniowego (Apium graveolens L. var. rapaceum /Mill./ DC). Biul. Warz. 39: 149-160.

Dobrzański A. 1994. Integracja metod ochrony warzyw przed chwastami z uwzględnieniem ograniczenia zużycia herbicydów. Materiały 34. Sesji Nauk. Inst. Ochr. Roślin, cz. 1: 104-110.

Dobrzański A. 1999. Ekologiczne podstawy ochrony przed chwastami. s. 8-29. W: „Ochrona warzyw przed chwastami” (A. Dobrzański, red.). PWRiL, Warszawa, 199 ss.

Christensen L., Brandt K. 2006. Bioactive polyacetylenes in food plants of the Apiaceae family: Occurrence, bioactivity and analysis. J. Pharm. Biomed. Anal. 41: 683-693.

Crozier A., Lean M.E.J., McDonald M.S., Black C. 1997. Quantitative analysis of the flavonoid content of commercial tomatoes, onions, lettuce and celery. J. Agric. Food Chem. 45 (3): 590-595.

Eldin A., Helaly A., Obiadalla-Ali H.A., Glala A.A.A. 2011. Yield and quality of celeriac (Apium graveolens var. rapaceum M.) as affect by harvesting dates and cultivars. J. Hortic. Sci. Ornam. Plants 3 (2): 137-142.

Greenberg D. 2012. Celebrating celeriac. www.cog.ca. Our Natur is Organic: 17-19.

Grundy A.C., Bond B. 2007. Use of non-living mulches for weed control. p. 135-153. In: "Non-Chemical Weed Management: Principles, Concepts and Technology" (M.K. Upadhyaya, R.E. Blackshaw, eds). CAB International, 239 pp.

Hertog M.G.K., Hollman P.C.H., Venema D.P. 1992. Optimization of a quantitative HPLC determination of potentially anticarcinogenic flavonoids in vegetables and fruits. J. Agric. Food Chem. 40 (9): 1591-1598.

Kunachowicz H., Nadolna I., Przygoda B., Iwanow K. 2005. Tabele składu i wartości odżywczej żywności. Wydawnictwa Lekarskie, PZWL, Warszawa: 244-251.

Lee Y., Howard L.R., Villaón B. 1995. Flavonoids and antioxidant activity of fresh pepper (Capsicum annuum) cultivars. J. Food Sci. 60 (3): 473-476.

Ostrowska A., Robak J. 2009. Wpływ nowych środków ochrony roślin stosowanych przedzbiorczo w ochronie selera na zdrowotność korzeni w okresie długotrwałego przechowywania. [The effect of new products used for pre-harvest protection of root celery and their influence on long-term storage]. Prog. Plant Prot./Post. Ochr. Roślin 49 (1): 252-255.

PN-90/A-75101/07. 1990. Przetwory owocowe i warzywne. Przygotowanie próbek i metody badań fizykochemicznych. Oznaczanie zawartości cukrów i ekstraktu bezcukrowego: $1-6$.

Pijanowski E., Mrożewski S., Horubała A. 1964. Technologia produktów owocowych i warzywnych. PWRiL, Warszawa, 634 ss.

Pitchford P. 2000. Odżywianie dla zdrowia. Wyd. Galaktyka, Łódź: 605-606.

Souci S.W., Fachmann W., Kraut H. 2000. Food Composition and Nutrition Tables, 6th edn. Medpharm Scientific Publishing, Deutsche Forschungsanstalt fur Lebensmittelchemie, Garching b. Munchen, Stuttgart, Germany (Boca Raton, London, New York, Washington, DC: CRC Press): 681-682.

Tsi D., Tan B.K. 2000. The mechanism underlying the hypocholesterolaemic activity of aqueous celery extract, its butanol and aqueous fraction in genetically hypercholesterolaemic rats. Life Sci. 66: 755-767.

Vinson J.A., Hao Y., Su X., Zubik L. 1998. Phenols antioxidant and quality in foods: Veg. J. Agric. Food Chem. 46 (9): $3630-3634$.

Weichmann J. 1977. CA Storage of celeriac. Acta Hort. (ISHS) 62: 109-118. 